\title{
Feeding an amino acid-formulated milk replacer for Holstein calves during 2 time periods
}

\author{
Ting Liu, ${ }^{1 *}$ () Kayla Hultquist, ${ }^{2}$ (ㅈ Kelly Froehlich, ${ }^{3}$ and David. P. Casper ${ }^{4}$ () \\ ${ }^{1}$ Faculty of Animal Science and Technology, Gansu Agricultural University, No. 1 Yingmen Village Anning, Lanzhou, 730070, China \\ ${ }^{2}$ Kent Nutrition Group, 2905 Highway 61 N, Muscatine, IA 52761 \\ ${ }^{3}$ Faculty of Agriculture and Life Science, Lincoln University, Canterbury, 7616 New Zealand \\ ${ }^{4}$ Casper's Calf Ranch, 4890 West Lily Creek Road, Freeport, IL 61032
}

\begin{abstract}
The milk-fed calf has a requirement for essential amino acids (EAA) instead of crude protein (CP). However, most milk replacers (MR) are still formulated to a CP concentration, and although limited amounts of Lys or Met may be added, these MR are not formulated solely on an AA basis. Previous work has demonstrated that feeding a modified MR balanced for specific EAA concentrations of a $24 \% \mathrm{CP} \mathrm{MR}$, but reducing $\mathrm{CP}$ to $22 \%$, resulted in improved growth performance in calves compared with a $24 \%$ CP MR. The 56-d objective was to determine if the hypothesis that an EAA MR formulated to the specific EAA concentrations of a $24 \%$ CP MR, but reducing CP to 22 (22AA) compared with a standard $22 \% \mathrm{CP}$ MR would result in similar or enhanced growth performance, while reducing feed costs. Two 56-d studies using forty 3- to 5-d-old Holstein bull calves per study received in 1 lot starting on May 8, 2018 (late-spring cooler) and June 22, 2018 (summer with heat stress) were blocked by body weight (BW) and randomly assigned to 1 of 2 MR treatments. Milk replacer treatments consisted of a standard 22:20 (CP: fat; $22 \mathrm{CP}$ ) and a 22:20 MR with greater EAA concentrations of a $24 \%$ CP MR (22AA). All MR, containing decoquinate and diflubenzuron, were fed at $0.57 \mathrm{~kg} / \mathrm{d}$ per calf split into 2 feedings at $0630 \mathrm{~h}$ and $1800 \mathrm{~h}$ for 0 to $14 \mathrm{~d}$ via bucket, increased to $0.85 \mathrm{~kg} / \mathrm{d}$ through $35 \mathrm{~d}$ split in 2 feedings, and fed once per day at 0.41 $\mathrm{kg} / \mathrm{d}$ in the morning with weaning after $42 \mathrm{~d}$. Calves were housed in straw-bedded hutches with ad libitum access to water and $25 \% \mathrm{CP}$ pelleted calf starter (CS). All data were analyzed as a randomized complete block design with block within study considered random and week as a repeated measurement. Initial BW was similar across all treatments $(39.9 \pm 2.32 \mathrm{~kg})$. Average
\end{abstract}

Received March 13, 2020.

Accepted June 17, 2020.

*Corresponding author: liuting0628@163.com daily temperature (i.e., heat stress intensity) tended to be greater for calves in study 2 compared with study 1 ( 20.5 and $22.9^{\circ} \mathrm{C}$ for study 1 and 2 , respectively). The interaction of study and MR effects were nonsignificant. Calf BW, BW gain, average daily gain, CS intake, total dry matter intake (MR plus CS), feed conversions, and EAA intake (MR plus CS) were similar for calves fed both MR. Study 2 (summer heat stress) resulted in more scours incidences compared with study 1 , and 22AA MR formulation tended to increase scours possibly due to synthetic AA addition or greater carbohydrate (lactose) inclusion when AA replaced protein sources. Feed costs as MR and total feed costs were lower for calves fed 22AA MR compared with calves fed 22CP MR. The increased Leu, Lys, Met, Thr, and Val concentrations in the 22AA MR compared with the $22 \mathrm{CP}$ MR resulted in similar calf growth performance, but the feed cost was lower for calves fed the 22AA MR, which achieved similar growth performance at a lesser cost under current study conditions, but not enhanced as hypothesized.

Key words: amino acids, calf, growth, heat stress, milk replacer

\section{INTRODUCTION}

Our previous work (Bai et al., 2020) demonstrated that reducing $\mathrm{CP}$ concentration in milk replacer (MR) by using synthetic AA to maintain AA intake equivalent to a higher CP MR improved growth performance and lowered feed cost. The calf requires EAA instead of $\mathrm{CP}$ for growth, even though MR are still formulated on a CP basis. The dairy NRC (2001) calf model predicts protein-limited and energy-limited growth performance, but the model does not predict EAA requirements. The use of synthetic EAA provides the opportunity to further define the EAA requirements for optimal growth performance at a potentially lower cost than CP.

Many studies show that calves will consume large amounts of milk or MR when offered (Jasper and Weary, 2002; Vieira et al., 2008; Borderas et al., 2009). 
However, weaning and postweaning ADG slump has plagued the success of some high MR feeding rate (FR) programs when calf starter (CS) was fed (Bar-Peled et al., 1997; Jasper and Weary, 2002; Hill et al., 2006). This resulted in a series of studies (Jaeger et al., 2020a,b,c) developing a modified accelerated MR program, which increased growth performance compared with calves fed other CP concentrations. Those studies optimized the CP:energy (fat) ratio, but EAA concentrations were not considered. Increased calf growth performance and no CS consumption slump was demonstrated by Bai et al. (2020) when feeding a 22\% CP MR balanced to specific EAA concentrations of a $24 \%$ CP MR compared with a standard $24 \% \mathrm{CP}$ formulated MR. Therefore, the development of a modified accelerated MR based on specific EAA formulation should minimize feed costs with the added benefit of supplying more EAA for lean tissue and frame growth during a standard 6-wk weaning program. Our hypothesis was that a 22 EAA MR formulated to the EAA concentration of a $24 \% \mathrm{CP}$ MR would enhance growth performance at a reduced feed cost compared with a standard $22 \% \mathrm{CP}$ formulated MR. The study objectives were to determine the growth performance of calves fed commercially available standard $22 \%$ CP MR compared with calves fed a $22 \%$ CP MR formulated to the EAA concentrations of a $24 \% \mathrm{CP}$ MR.

\section{MATERIALS AND METHODS}

The following 2 experiments reported were conducted using the same facilities, experimental design, procedures, and sample collection as previously published in Bai et al. (2020). The experimental materials and methods are briefly reported below.

\section{Calf Management and Feeding}

The 2 experiments were conducted at Casper's Calf Ranch (Freeport, IL). The first experiment started on May 8, 2018 (study 1) and the second experiment started on June 22, 2018 (study 2). The calves were managed and fed according to the guidelines published in the Care and Use of Agricultural Animals in Research and Teaching (FASS, 2010), as well as the Chinese Standards for the Use and Care of Research Animals (He et al., 2016).

Both experiments started with forty 3- to 5-d-old Holstein bull calves sourced by a commercial calf buyer (Knueppel Livestock, Shawno, WI) and delivered either on Tuesday (study 1) or Thursday night (study 2). Calves were purchased through several livestock auction barns and represented commingled calves sourced from numerous dairy farms. Calves were assumed to have been fed colostrum at the dairy farms, but no blood samples were collected for measurement of total serum protein due to the concern of transportation stress and dehydration biasing the results (Guzelbektes et al., 2007). Calves were vaccinated upon arrival with Inforce 3 (Zoetis Inc. Florham Park, NJ) and placed in a chopped wheat straw-bedded calf hutch (measuring $220 \times 122 \times 38 \mathrm{~cm}$; Calf-Tel Deluxe II, Hampel, Germantown, WI) that was placed on a grass pasture in an open, naturally well-ventilated area. Hutches were spaced $0.6 \mathrm{~m}$ apart in rows of 10 hutches. Each hutch had a $183 \mathrm{~cm} \times 122 \mathrm{~cm} \times 107 \mathrm{~cm}$ wire panel attached to the front with 2 bucket holders $(0.65 \mathrm{~m}$ high) for 8-L plastic buckets. One bucket contained ad libitum fresh water and the other bucket contained a pelleted CS. The water bucket was emptied at each feeding and filled with the appropriate experimental MR at the designated FR. Upon completion of milk consumption, the bucket was rinsed and filled with fresh water. Calves were fed the control $22 \mathrm{CP}$ MR the next morning after arrival during the night. After the morning feeding, calves were weighed and their frame measurements collected. Calves were then blocked by BW and randomly assigned to 1 of $2 \mathrm{MR}$ treatments. Treatments were: (1) a standard formulation of $22 \% \mathrm{CP}$ MR $(\mathbf{2 2} \mathbf{C P})$ that is commercially available and (2) an AA-formulated MR with the EAA concentrations of a $24 \% \mathrm{CP}$ MR, but the $\mathrm{CP}$ reduced to $22 \%(\mathbf{2 2 A} \mathbf{A})$. All MR contained $20 \%$ fat, decoquinate (Deccox, Zoetis Inc., Parsippany, $\mathrm{NJ}$ ) added at the rate of $41.7 \mathrm{mg} / \mathrm{kg}$ (as-is basis) for coccidiosis control, and $16 \mathrm{mg} / \mathrm{kg}$ diflubenzuron (as fed MR basis; ClariFly, Central Life Sciences, Schaumburg, IL) for fly control. The ingredient composition of the MR is given in Table 1 .

The MR feeding time was fixed at 0630 and $1800 \mathrm{~h}$ and the feeding sequence was kept consistent with the $22 \mathrm{CP}$ fed first, shuttle rinsed, followed by the 22AA. Each MR was accurately weighed (model ACE110, Smart Weigh Inc., Hurricane, WV) and mixed with the appropriate amount of hot water $\left(46^{\circ} \mathrm{C}\right)$ using an Urban Milk Shuttle (Urban GmbH and Co., Hamburg, Germany). The shuttle and its computerized mixing, heating, and delivery systems were calibrated to ensure an accurate delivery of a homogeneously mixed MR fed at a temperature of $37.5^{\circ} \mathrm{C}$ or greater at the correct volume. Each experimental MR was fed at the rate of $0.57 \mathrm{~kg} /$ calf daily for the first $14 \mathrm{~d}$, then increased to $0.85 \mathrm{~kg} /$ calf daily divided into 2 equal feedings (i.e., morning and evening). For 5 d during wk 5 (d 30-35), Amprolium (Merial, LLC., Duluth, GA) was added at the rate of $10 \mathrm{mg} / \mathrm{kg}$ of $\mathrm{BW}$ to the experimental $\mathrm{MR}$ for the coccidiosis control. Starting on d 36 through d 42 , the MR FR was decreased to $0.425 \mathrm{~kg} /$ calf fed once per day at the morning feeding to facilitate weaning. 
Table 1. Ingredient composition of milk replacers (MR) formulated for $22 \% \mathrm{CP}(22 \mathrm{CP})$ or containing greater AA concentrations (22AA) equal to $24 \% \mathrm{CP}^{1}$

\begin{tabular}{|c|c|c|}
\hline \multirow[b]{2}{*}{ Ingredient } & \multicolumn{2}{|c|}{$\mathrm{MR}^{2}$} \\
\hline & $22 \mathrm{CP}$ & $22 \mathrm{AA}$ \\
\hline Whey (whey protein concentrate) & 58.1 & 54.5 \\
\hline Fat base & 38.8 & 40.2 \\
\hline Dicalcium phosphate & 0.47 & 0.78 \\
\hline L-Lysine $\mathrm{HCl}$ & - & 1.07 \\
\hline Decoquinate $0.5 \%$ & 1.00 & 1.00 \\
\hline Vitamin premix & 0.91 & 0.91 \\
\hline DL-Methionine & 0.16 & 0.45 \\
\hline Organic trace mineral premix ${ }^{3}$ & 0.38 & 0.38 \\
\hline Bioplus $2 \mathrm{~B}^{4}$ & 0.05 & 0.05 \\
\hline Clarify $8 \%^{5}$ & 0.02 & 0.02 \\
\hline Flavor $^{6}$ & 0.06 & 0.06 \\
\hline Threonine & - & 0.29 \\
\hline Stay Strong (oregano) ${ }^{7}$ & 0.10 & 0.10 \\
\hline L-Valine & - & 0.11 \\
\hline Vitamin E & 0.09 & 0.09 \\
\hline L-Leucine & - & 0.09 \\
\hline
\end{tabular}

${ }^{1}$ Tag guarantee of $22 \%$ CP, $20 \%$ fat, not less than $55,000 \mathrm{IU}$ of vitamin A, 16,500 IU of vitamin D, and $220 \mathrm{IU}$ of vitamin E per kilogram on an as-fed basis. Manufactured by Milk Specialties Global, Eden Prairie, MN.

${ }^{2}$ Reported as percent of mix.

${ }^{3}$ Milk Specialties Global.

${ }^{4} \mathrm{Chr}$. Hansen, Milwaukee, WI.

${ }^{5}$ Diflubezuron, Central Life Sciences, Schaumburg, IL.

${ }^{6}$ Milk Specialties Global.

${ }^{7}$ Ralco Nutrition Inc., Marshall, MN.

All experimental MR were fed at $15 \%$ solids, and if any calf did not consume its milk, the refused volume was recorded. Starting on d 1, a 2.4-mm mini-pelleted $22 \%$ CP CS (as-is basis; Table 2) and water were offered ad libitum throughout the study. All experimental MR were manufactured and supplied by Milk Specialties (Eden Prairie, MN) and CS was manufactured and supplied by Furst-McNess (Freeport, IL). All MR and CS were manufactured in sufficient quantities at 1 time for each experiment to complete the study using the same lots of ingredients (Tables 1 and 2). At the completion of the 56-d experimental period, calves were then dehorned via hot iron, castrated using a scalpel to remove the scrotum bottom, had their testes physically removed by a licensed veterinarian (Bardon Scharping, Lena Veterinary Clinic, Lena, IL), and then sold to a privately owned commercial feed lot.

\section{Weather Data}

Weather data were downloaded from a local personal weather station site for Freeport, IL located at $42.301^{\circ}$ $\mathrm{N}, 89.665^{\circ} \mathrm{W}$ at an elevation of $256.9 \mathrm{~m}$, approximately $5 \mathrm{~km}$ from the research location. The temperaturehumidity index (THI) was calculated according to the equation of Vitali, et al. (2009) based on the weather station data for daily minimum, average, and maximum THI values. A THI value of $<72$ was considered no heat stress, 72 to 79 was considered mild, 80 to 89 was considered moderate, and $>90$ was considered severe heat stress. Although these ranges are based on heat stress in lactating dairy cows, these ranges should be applicable to calves based on limited literature data (Roland et al., 2016).

\section{Feed Intake and Analysis}

Starting on d 1, the amounts of CS offered and refusal weights were recorded daily using a digital scale (model ACE110, Smart Weigh Inc., Hurricane, WV). For days that feed was wet (i.e., rain), that day's data was eliminated and the remaining days during that week were compiled into weekly means of CS intake. Samples of each experimental MR and CS were collected weekly and stored frozen at $-20^{\circ} \mathrm{C}$ until composited at the end of the study. Samples collected during wk 1, 2, and 3 or wk 4,5 , and 6 were composited into 2 samples for each experimental MR, and CS samples collected during wk $1,2,3$, and 4 or wk $5,6,7$, and 8 were composited into

Table 2. Ingredient composition of pelleted calf starter $(\mathrm{CS})^{1}$

\begin{tabular}{lc}
\hline Ingredient & CS $(\%)$ \\
\hline Wheat middlings & 35.0 \\
Soybean meal, 48 & 25.5 \\
Corn, fine ground & 22.5 \\
Molasses mixer $^{\text {Distiller's grains with solubles }}{ }^{2}$ & 5.50 \\
Calcium carbonate & 5.00 \\
Corn starch & 2.25 \\
Salt & 1.25 \\
Sodium bentonite & 1.10 \\
Soy oil & 0.50 \\
Bovine B premix ${ }^{3}$ & 0.43 \\
Vitamin A premix ${ }^{4}$ & 0.25 \\
Vitamin E premix & 0.18 \\
Dairy trace mineral premix & 6 \\
Vitamin D premix & \\
Clarify 0.67\% larvicide (diflubenzuron) & 0.16 \\
Cherry flavor & 0.13 \\
Selenium 0.06\% & 0.07 \\
Rumensin 198.4 g/kg (monensin) & 0.05 \\
\hline
\end{tabular}

${ }^{1}$ Manufactured by McNess, Freeport, IL. Reported as percent of mix. ${ }^{2}$ Fermented corn byproduct.

${ }^{3}$ Bovine B contains biotin $10.5 \mathrm{mg} / \mathrm{kg}$, choline $167.6 \mathrm{~g} / \mathrm{kg}$, folic acid $50.3 \mathrm{mg} / \mathrm{kg}$, niacin $94 \mathrm{~g} / \mathrm{kg}$, pantothenic acid $10.5 \mathrm{~g} / \mathrm{kg}$, pyridoxine $4.4 \mathrm{mg} / \mathrm{kg}$, riboflavin $4.4 \mathrm{~g} / \mathrm{kg}$, thiamine $1.1 \mathrm{~g} / \mathrm{kg}$, and vitamin $\mathrm{B}_{12}$ $19.8 \mathrm{mg} / \mathrm{kg}$.

${ }^{4}$ Vitamin A premix contains 11,050,072 IU/kg.

${ }^{5}$ Vitamin E premix contains 44,750 IU/kg.

${ }^{6}$ Trace mineral premix contains cobalt $1,350 \mathrm{mg} / \mathrm{kg}$, copper 23,500 $\mathrm{mg} / \mathrm{kg}$, iodine $2,000 \mathrm{mg} / \mathrm{kg}$, manganese $100,000 \mathrm{mg} / \mathrm{kg}$, selenium 510 $\mathrm{mg} / \mathrm{kg}$, and zinc $125,000 \mathrm{mg} / \mathrm{kg}$.

${ }^{7}$ Vitamin D premix contains 8,375,055 IU/kg. 
2 lots. One water sample was collected from the water supply used for both mixing MR and free choice water offered. Feed and water samples were submitted to Cumberland Valley Analytical Services (Waynesboro, PA) for nutrient analyses. Samples of MR were analyzed using the following AOAC International (2019) methods for DM (930.15), CP (990.03), acid hydrolysis fat (954.02), NDF (2002.04), ash (942.05), Ca (985.01), $\mathrm{P}$ (985.01), Mg (985.01), K (985.01), S (923.01), Na (985.01), Cu (985.01), Fe (985.01), Mn (985.01), and Zn (985.01). Calf starter samples were analyzed for DM (930.15), CP (990.03), soluble protein (Krishnamoorthy et al., 1982), NDF (2002.04), ADF (973.18), lignin (973.18), NDF insoluble protein (2002.04 without sulfite and 976.06), ADF insoluble protein (973.18 and 976.06), water soluble sugar (DuBois et al., 1956), starch (Hall, 2009), fat (2003.05), ash (942.05), Ca (985.01), $\mathrm{P}$ (985.01), Mg (985.01), K (985.01), S (923.01), Na (985.01), Cu (985.01), Fe (985.01), Mn (985.01), and Zn (985.01). Chloride for both MR and CS samples were extracted with $0.5 \%$ nitric acid and analyzed by potentiometric titration with silver nitrate (Metrohm 848 Titrino Plus, Metrohm, Riverview, FL). Nonfiber carbohydrates were calculated using the following equation: NFC $=\{100-[(\mathrm{NDF}-\mathrm{NDF}$ insoluble protein $)+$ $\mathrm{CP}+$ fat $+\mathrm{ash}]\}$, and $\mathrm{ME}(\mathrm{Mcal} / \mathrm{kg})$ was calculated for MR and CS using the equations of Quigley (2007) and NRC (2001). Samples of experimental MR and CS were sent to the Agricultural Experiment Station Chemical Laboratories at the University of Missouri-Columbia for AA analysis (AOAC International, 2019; method 982.30E). For all AA except cystine, methionine, and tryptophan, a test portion was hydrolyzed in $6 \mathrm{M} \mathrm{HCl}$ at $110^{\circ} \mathrm{C}$ in an atmosphere free of oxygen for $24 \mathrm{~h}$. The hydrolysate was filtered to remove carbon and brought to a specified volume. An aliquot of the filtrate was evaporated to dryness under vacuum. The AA residue was dissolved in a buffer and injected into an AA analyzer. For cystine and methionine, a test portion was mixed with cold performic acid and allowed to stand overnight between 0 and $5^{\circ} \mathrm{C}$ to convert methionine to methionine sulfone and cysteine and cystine to cysteic acid. The performic acid mixture was then neutralized with cold hydrobromic acid and evaporated to dryness under vacuum. The residue was then hydrolyzed in acid as described previously. For tryptophan, a test portion was hydrolyzed in $4 \mathrm{M} \mathrm{NaOH}$ under vacuum for $22 \mathrm{~h}$ at $110^{\circ} \mathrm{C}$. The hydrolysate was neutralized with $\mathrm{HCl}$ and diluted to a specified volume using a buffer. Aliquots of the prepared hydrolysates were injected onto an AA analyzer (Hitachi Model 8900, Hitachi, Schaumberg, IL) that used the classical ion exchange resolution and ninhydrin postcolumn derivatization method developed by Moore and Stein (1963).
To evaluate MR solubility, we mixed a typical MR feeding of $0.425 \mathrm{~kg}$ with $2.85 \mathrm{~L}$ of $110^{\circ} \mathrm{C}$ water, let it sit for 5 to $10 \mathrm{~min}$ (approximate consumption time by calf), and then filtered it through 4 layers of cheesecloth. The cheesecloth was dried and weighed before and after filtering the individual MR samples to determine the amount of residue remaining on the cheesecloth. Each experimental composite MR sample was replicated 3 times.

\section{Body and Health Measurements}

Body weights were measured weekly using a Wrangler Jr. digital scale (Digi-Star, LLC, Fort Atkinson, WI) placed on a $1.2 \mathrm{~m} \times 2.4 \mathrm{~m}$ sheet of $1.9 \mathrm{~cm}$ thick sheet of plywood towed by a John Deere 825 Gator (John Deere, Moline, IL). Body weights were taken after the morning feeding starting at approximately $0900 \mathrm{~h}$ each week. Hip height $(\mathbf{H H})$ and withers height (WH) were measured using a Ketchum Teletape with a level mounted on top (Ketchum Manufacturing Inc., Brockville, Canada). Body length (BL) and heart girth (HG) were measured using a Nasco dairy calf weigh tape (Nasco, Fort Atkinson, WI). Body measurements were taken the same time as BW, but only every $4 \mathrm{wk}$ (i.e., wk 0, 4, and 8).

Calf health, along with fecal, nasal, and ear/eye scores were monitored daily during the experiments. Health scores were visually assessed before the evening feeding according to the University of Wisconsin calf health scoring chart (McGuirk, 2013) based on a scale of 0 to 3. Fecal scores were established as 0 (normal), 1 (semi-formed or pasty), 2 (loose but stays on top of bedding), and 3 (watery or sifts through bedding). Nasal scores were established as 0 (normal serous discharge), 1 (small amount of unilateral cloudy discharge), 2 (bilateral, cloudy, or excessive mucus discharge), and 3 (copious bilateral mucopurulent discharge). Eye/ear scores were established as 0 (normal), 1 (small amount of ocular discharge with ear flick or head shake), 2 (moderate amount of bilateral ocular discharge or slight unilateral droop), and 3 (heavy ocular discharge, head tilt, or bilateral droop). In the case of illness, body temperature was measured using a rectal thermometer (Zoe+Ruth, Portland, OR) and appropriate medical treatments prescribed by a licensed veterinarian (Brandon Scharping, Lena, IL) were administered if needed. All health incidents and treatments were recorded during the study.

\section{Economic Analysis}

The time point of March 2019 was selected to calculate the feed costs to raise the calves. Retail prices of 
MR and CS were based on Furst-McNess's retail price list to the dairy producer and did not include freight costs. Data on BW gain, MR intake, and CS intake were used with retail product pricing to calculate the feed costs for MR, CS, total DMI, and dollars per kilogram of BW gain. Retail MR prices were $\$ 2.91$ and $\$ 2.78 / \mathrm{kg}$, and CS was $\$ 0.43 / \mathrm{kg}$. Per the study's hypothesis, using synthetic AA to meet the AA specifications in the MR formulation while reducing $\mathrm{CP}$ concentration caused a reduction in the ingredient cost, resulting in a more economical MR that meets the AA concentrations of a $24 \% \mathrm{CP}$ MR, (i.e., $\$ 2.91$ versus $\$ 2.78$ for $22 \mathrm{CP}$ and $22 \mathrm{AA}$, respectively).

\section{Statistical Analysis}

All data were checked for normality and outliers using the UNIVARIATE procedure of SAS (version 9.4, SAS Institute Inc., Cary, NC) before any statistical analyses were conducted. Two calves from study 2 were identified as statistical outliers, and their individual growth data indicated that these 2 calves were stunted for unknown reasons. The box and whisker plots and the Shapiro Wilk test were then used to verify that the remaining data were normally distributed $(P>0.10)$. All data were then subjected to least squares ANOVA for a randomized complete block design (Steele and Torrie, 1980) in a $2 \times 2$ factorial arrangement of treatments via the MIXED procedure of SAS with study week as a repeated measure ANOVA. The statistical model used was as follows:

$$
\begin{gathered}
Y_{i j k}=\mu+\operatorname{Rep}(\text { Study })_{i}+\text { Study }_{j}+M R_{k} \\
+\left(\text { Study }_{j} \times M R_{k}\right)+W_{1}+\left(M R_{k} \times W_{l}\right) \\
+\left(\text { Study }_{j} \times W_{l}\right)+\left(\text { Study }_{j} \times M R_{k} \times W_{1}\right) \\
+\operatorname{Cov}+e_{i j k l},
\end{gathered}
$$

where $Y_{i j k l}=$ dependent variable, $\mu=$ overall mean, $\operatorname{Rep}(S t u d y)_{i}=$ replication nested within study, Study = study, $M R_{k}=\mathrm{MR}_{\mathrm{k}}, S t u d y_{j} \times M R_{k}=$ study by $\mathrm{MR}$ interaction, $W_{k}=$ week of study, Study $y_{j} \times W_{k}=$ study by week interaction, $M R_{k} \times W_{l}=$ MR by week interaction, Study $y_{j} \times M R_{k} \times W_{l}=$ study by MR by week interaction, $C o v=$ covariate (initial measurement when appropriate), and $e_{i j k}$ is the residual random error. Study, MR, week, and all interactions were considered fixed effects, and replication nested with study was considered a random effect. Study week was considered a repeated measurement in time having an autoregressive covariance structure. Least squares means were separated by PDIFF statement when the F-test for MR was significant. All other data were summarized using the same model described above, but excluded week. Initial BW and frame measurements were tested as a covariate for their respective parameters, but did not improve statistical significance $(P>0.15)$, and therefore excluded from the model. Significance was declared at $P<0.05$ and trends at $0.05<P \leq 0.10$. Daily feed intake and orts measurements were compiled as weekly averages and DM and AA intakes were calculated. Each daily fecal, nasal, and eye/ear scores were summarized by tallying (by week) the number of days with a specific score (i.e., number of days with a score of 0 ) and analyzed as weekly averages. The second method was to total the number of days of a specific score for the entire 6 -wk MR phase of the study.

\section{RESULTS AND DISCUSSION}

\section{Mixability and Nutrient Composition of Water and Feeds}

The remaining residue amount after mixing a typical MR feeding $(\sim 0.41 \mathrm{~kg})$ with $110^{\circ} \mathrm{C}$ water was similar $(P>0.93)$ for calves fed both MR $(0.84$ and $0.83 \%$ for $22 \mathrm{CP}$ and $22 \mathrm{AA}$, respectively; $\mathrm{SEM}=0.07)$. Mixability is always a concern with the development of new MR because residues left in the container after feeding are a concern both to the calf (unable to consume all of the allotted nutrients) and the person feeding the calves (who notices the residue remaining). Both MR mixed easily and stayed in suspension to ensure accurate and precise feeding.

The water nutrient composition was typical of water sourced from a northern Illinois well with a $\mathrm{pH}$ of 7.08 and the following concentrations: nitrate $=2.42 \mathrm{mg} /$ $\mathrm{kg}$, total dissolved solids $=374 \mathrm{mg} / \mathrm{kg}, \mathrm{Ca}=76.5 \mathrm{mg} /$ $\mathrm{kg}, \mathrm{Mg}=39.8 \mathrm{mg} / \mathrm{kg}, \mathrm{Na}=6.9 \mathrm{mg} / \mathrm{kg}, \mathrm{Cl}=14 \mathrm{mg} /$ $\mathrm{kg}, \mathrm{P}<0.10 \mathrm{mg} / \mathrm{kg}, \mathrm{K}<1 \mathrm{mg} / \mathrm{kg}, \mathrm{Fe}$ and $\mathrm{Mn}<0.05$ $\mathrm{mg} / \mathrm{kg}$, and $\mathrm{Cu}$ and $\mathrm{Zn}<0.01 \mathrm{mg} / \mathrm{kg}$. The water was considered hard water $(360 \mathrm{mg} / \mathrm{kg})$ due to the high Ca and $\mathrm{Mg}$ concentrations, which are related to the total dissolved solids. Total dissolved solids above $960 \mathrm{mg} /$ $\mathrm{kg}$ can limit water intake by livestock, but the amount of $\mathrm{Ca}$ and $\mathrm{Mg}$ in the water would not be likely to affect water intake or growth performance by dairy cattle (Beede, 2012). The trace minerals Fe, Mn, Zn, and $\mathrm{Cu}$ are known to limit water intake and livestock performance if concentrations are excessive (Beede, 2012), but in this study all trace minerals were below detection limits of the laboratory's analytical procedures.

The nutrient composition of the $2 \mathrm{MR}$ fed to the calves in this study indicated that the nutrient composition met or slightly exceeded formulated specifications for $\mathrm{CP}$ and minerals (Table 3 ). There was a small trend $(P<0.10)$ for higher DM concentration 
of the 22AA MR, probably due to the replacement of whey protein concentrates with synthetic EAA. There were no differences $(P>0.10)$ in $\mathrm{CP}$, SP, NDF, Mn, $\mathrm{Zn}$, and $\mathrm{Cu}$ concentrations among the $2 \mathrm{MR}$. However, concentrations of ME, $\mathrm{K}$, and $\mathrm{Na}$ tended to be lower $(P$ $<0.10)$, and ADF, Ca, $\mathrm{P}, \mathrm{Mg}(P<0.05)$, and ash $(P$ $<0.01$ ) were lower for MR 22AA compared with MR $22 \mathrm{CP}$. In contrast, NFC concentrations were higher $(P$ $<0.05)$ for MR 22AA compared with MR 22CP. Substitution of synthetic EAA to meet formulation specifications instead of whey protein concentrate reduced whey protein concentrate inclusion rates, allowing for greater inclusion of carbohydrates (i.e., lactose) because fat concentration is fixed. These nutrient concentrations would meet or exceed the nutrient requirement guidelines for neonatal calves (NRC, 2001). The minipelleted CS met or exceeded formulation specifications $(>25.2 \% \mathrm{CP}, \mathrm{DM}$ basis $)$ to provide the nutrients to meet or exceed the NRC (2001) nutrient requirement guidelines for growing Holstein dairy calves (Table 3).

Formulating a MR to Leu, Lys, Met, Thr, Trp, and Val specifications of a $24 \% \mathrm{CP}$ while reducing $\mathrm{CP}$ to $22 \%$ resulted in EAA concentration differences (22AA) compared with formulating a standard $22 \%$ CP MR (22CP) without AA specifications (Table 4). For example, the concentrations of Arg, His, and Ile were higher for MR 22CP compared with MR 22AA. Formulating to the specific specifications of Leu, Lys, Met, Thr, Trp, and Val ensured that the animals' requirements for these EAA responsible for growth were closer to being met for optimal growth compared with MR $22 \mathrm{CP}$. The 22 CP MR may or may not meet the animals' specific EAA requirements due to changes in ingredients, and especially ingredient prices, to meet the formulation specification of a $22 \% \mathrm{CP}$ MR $(22 \mathrm{CP})$, as these can change with reformulation. Bai et al. (2020) reported that formulating MR only to $\mathrm{CP}$ specifications can result in variable AA concentrations from batch to batch within each MR due to use of different $\mathrm{CP}$ ingredients based on costs, ingredient availability, and nutrient variability. Thus, formulating a MR to specific EAA concentrations (Leu, Lys, Met, Thr, Trp, and Val) ensures that the EAA requirements of the calf can be better managed without over- or under-supplementation of any specific EAA, with the potential of reducing the $\mathrm{CP}$ concentration and ultimately reducing ingredient costs. It is interesting to note that formulation of the $22 \mathrm{AA} \mathrm{MR}$ required the addition of 5 of the 6 synthetic AA offered to the formulation matrix, and the total EAA concentrations were similar at the conclusion $(P$ $>0.10)$. Methionine and Lys are usually considered the first 2 limiting AA (Hill et al., 2007); however, given

Table 3. Nutrient composition of milk replacer formulated for $22 \% \mathrm{CP}$ (22CP) or containing greater AA concentrations (22AA) equal to $24 \% \mathrm{CP}$ and pelleted calf starter ${ }^{1}$

\begin{tabular}{|c|c|c|c|c|c|c|}
\hline \multirow[b]{2}{*}{ Item } & \multicolumn{2}{|c|}{ Milk replacer } & \multirow[b]{2}{*}{ SEM } & \multicolumn{2}{|c|}{$P$-value ${ }^{2}$} & \multirow[b]{2}{*}{ SD } \\
\hline & $22 \mathrm{CP}$ & $22 \mathrm{AA}$ & & Study & Calf starter & \\
\hline $\mathrm{N}$ & 4 & 4 & - & - & 8 & - \\
\hline DM, \% & 97.1 & $97.7 \dagger$ & 0.17 & 0.12 & 87.2 & 0.68 \\
\hline $\mathrm{CP}, \%$ & 22.4 & 22.6 & 0.18 & 0.20 & 25.5 & 0.48 \\
\hline $\mathrm{SP}^{3} \%$ of $\mathrm{CP}$ & 21.6 & 21.9 & 0.16 & 0.37 & 21.6 & 2.71 \\
\hline $\mathrm{ADF}, \%$ & 1.22 & $0.73^{*}$ & 0.13 & 0.23 & 8.04 & 0.29 \\
\hline NDF, $\%$ & 1.23 & 1.60 & 0.29 & 0.34 & 21.1 & 1.24 \\
\hline NFC, \% & 56.7 & $63.3^{*}$ & 1.75 & 0.12 & 40.5 & 1.40 \\
\hline Starch, \% & - & - & - & - & 25.0 & 1.03 \\
\hline Crude fat, \% & - & - & - & - & 3.76 & 0.16 \\
\hline $\mathrm{ME},{ }^{4} \mathrm{Mcal} / \mathrm{kg}$ & 4.82 & $4.89 \dagger$ & 0.03 & 0.03 & 2.75 & 0.04 \\
\hline Ash, $\%$ & 9.86 & $7.49^{* *}$ & 0.34 & 0.74 & 9.20 & 0.81 \\
\hline $\mathrm{Ca}, \%$ & 1.16 & $1.11^{*}$ & 0.01 & 0.16 & 1.51 & 0.18 \\
\hline $\mathrm{P}, \%$ & 0.80 & $0.72^{*}$ & 0.02 & 0.74 & 0.80 & 0.03 \\
\hline $\mathrm{Mg}, \%$ & 0.15 & $0.14^{*}$ & 0.003 & 0.13 & 0.37 & 0.02 \\
\hline $\mathrm{K}, \%$ & 2.17 & $1.68 \dagger$ & 0.15 & 0.17 & 1.53 & 0.25 \\
\hline $\mathrm{Na}, \%$ & 0.86 & $0.60 \dagger$ & 0.84 & 0.18 & 0.56 & 0.12 \\
\hline $\mathrm{Fe}, \mathrm{mg} / \mathrm{kg}$ & 86.0 & $103.0 \dagger$ & 5.59 & 0.91 & 269 & 31.4 \\
\hline $\mathrm{Mn}, \mathrm{mg} / \mathrm{kg}$ & 36.0 & 33.3 & 4.07 & 0.24 & 190 & 24.7 \\
\hline $\mathrm{Zn}, \mathrm{mg} / \mathrm{kg}$ & 110.8 & 116.5 & 5.03 & 0.01 & 287 & 93.8 \\
\hline $\mathrm{Cu}, \mathrm{mg} / \mathrm{kg}$ & 13.3 & 10.8 & 1.07 & 0.76 & 53.4 & 13.6 \\
\hline
\end{tabular}

${ }^{1}$ Analyses conducted by Cumberland Valley Analytical Services (Waynesboro, PA).

${ }^{2} F$-test for probability that study 1 versus study 2 differ.

${ }^{3} \mathrm{SP}=$ soluble protein.

${ }^{4}$ Metabolizable energy was calculated using equations from Quigley (2007) or NRC (2001).

$\dagger,{ }^{*},{ }^{* *}$ Means differ, $P<0.10, P<0.05, P<0.01$, respectively. 
Table 4. Amino acid composition of milk replacer formulated for $22 \% \mathrm{CP}(22 \mathrm{CP})$ or containing greater AA concentrations (22AA) equal to $24 \% \mathrm{CP}$ and pelleted calf starter ${ }^{1}$

\begin{tabular}{|c|c|c|c|c|c|c|}
\hline \multirow[b]{2}{*}{ Item } & \multicolumn{2}{|c|}{ Milk replacer } & \multirow[b]{2}{*}{ SEM } & \multicolumn{2}{|c|}{$P<^{2}$} & \multirow[b]{2}{*}{$\mathrm{SD}$} \\
\hline & 22 & $22 \mathrm{AA}$ & & Study & Calf starter & \\
\hline $\mathrm{N}$ & 4 & 4 & - & - & & \\
\hline $\mathrm{DM}, \%$ & 96.5 & $97.0^{* *}$ & 0.04 & 0.01 & 88.1 & 0.57 \\
\hline \multicolumn{7}{|l|}{$\mathrm{AA}, \%$ of $\mathrm{DM}$} \\
\hline Arg & 0.61 & $0.58^{* *}$ & 0.004 & 0.47 & 1.61 & 0.09 \\
\hline His & 0.46 & $0.44^{* *}$ & 0.003 & 0.01 & 0.66 & 0.04 \\
\hline Ile & 1.39 & $1.31^{* *}$ & 0.004 & 0.01 & 1.04 & 0.05 \\
\hline Leu & 2.25 & $2.32^{* *}$ & 0.01 & 0.81 & 1.93 & 0.03 \\
\hline Lys & 1.99 & $2.71^{*}$ & 0.16 & 0.69 & 1.34 & 0.07 \\
\hline Met & 0.60 & $0.84^{*}$ & 0.03 & 0.25 & 0.35 & 0.01 \\
\hline Phe & 0.78 & 0.75 & 0.01 & 0.58 & 1.18 & 0.04 \\
\hline Thr & 1.48 & $1.60 \dagger$ & 0.03 & 0.32 & 0.88 & 0.02 \\
\hline Trp & 0.40 & $0.38^{*}$ & 0.004 & 0.02 & 0.30 & 0.02 \\
\hline Val & 1.36 & $1.41 \dagger$ & 0.01 & 0.22 & 1.22 & 0.05 \\
\hline Total EAA, $\%$ of DM & 11.3 & 12.3 & 0.18 & 0.11 & 10.5 & 0.37 \\
\hline Ala & 1.08 & $1.02^{* *}$ & 0.005 & 0.06 & 1.20 & 0.02 \\
\hline Asp & 2.26 & $2.13^{* *}$ & 0.01 & 0.87 & 2.33 & 0.13 \\
\hline Cys & 0.49 & $0.45^{* *}$ & 0.004 & 0.01 & 0.41 & 0.02 \\
\hline Gly & 0.51 & $0.47^{* *}$ & 0.002 & 0.01 & 1.09 & 0.05 \\
\hline Glu & 3.61 & $3.43^{* *}$ & 0.01 & 0.01 & 4.33 & 0.18 \\
\hline Pro & 1.30 & 1.26 & 0.02 & 0.03 & 1.42 & 0.04 \\
\hline Ser & 0.98 & $0.93^{*}$ & 0.01 & 0.01 & 0.97 & 0.04 \\
\hline Tyr & 0.67 & $0.63^{*}$ & 0.01 & 0.09 & 0.82 & 0.02 \\
\hline Total NEAA, $\%$ of DM & 11.0 & 10.5 & 0.06 & 0.13 & 12.8 & 0.48 \\
\hline Total AA, $\%$ of DM & 22.4 & 22.7 & 0.21 & 0.87 & 23.3 & 0.84 \\
\hline $\mathrm{CP}, \%$ & 22.6 & $22.8^{*}$ & 0.05 & 0.01 & 24.8 & 0.24 \\
\hline
\end{tabular}

further reductions in $\mathrm{CP}$ concentrations could result in another EAA becoming limiting (i.e., Leu, Thr, Trp, and Val). If these EAA are critical for calf growth performance, then formulating for these specific EAA will ensure consistent animal growth performance over time, (i.e., manufacture batch to batch). For example, calves fed the 22CP MR would have greater intake of several lesser limiting important EAA than calves fed the 22AA by formulating to a $\mathrm{CP}$ specification.

The non-EAA concentrations of Ala, Asp, Cys, Gly, Glu, Ser, and Tyr were lower $(P<0.05)$ for MR 22AA compared with MR 22CP, and concentrations of Pro, total non-EAA, and total AA concentrations were similar $(P>0.10)$. It would be expected that formulating to specific EAA concentrations using synthetic EAA would reduce the non-EAA concentrations by altering the inclusion amounts of whey and milk protein ingredients (Table 1).

\section{Weather Data}

Although the timeline for these studies does not precisely match up with a spring versus summer weather comparison, the maximum, average, and minimum dai- ly temperatures and calculated THI tended $(P<0.13)$ to be higher during study 2 compared with the study 1 time period (Table 5). Thus, calves in study 2 were experiencing greater heat stress than calves in study 1. During study 2, the maximum daily temperatures tended to be higher $(P<0.13)$, but the daily nighttime temperatures also tended to be higher $(P<0.11)$ compared with study 1 , which can affect the calf's ability to dissipate heat. Calves in both studies experienced minimum THI values that indicated no heat stress, but calves in study 2 experienced moderate heat stress (THI >80) compared with study 1 calves. Spiers et al. (2001) reported that livestock typically dissipate heat during nighttime, such that nighttime cooling is important for coping with daytime heat stress. Although the maximum daily dew point temperatures were similar $(P>0.19)$ for study 1 compared with study 2 , the average and minimum daily dew point temperatures tended $(P<0.12)$ to be higher for calves in study 2 compared with calves in study 1 . Maximum, average, and minimum relative humidity and windspeed measurements were similar $(P>0.15)$ for both studies. Maximum, average, and minimum barometric pressure were higher $(P<0.06)$ in study 2 compared with study 
Table 5. Weather data when studies 1 and 2 were conducted

\begin{tabular}{|c|c|c|c|c|}
\hline \multirow[b]{2}{*}{ Measurement } & \multicolumn{2}{|c|}{ Study } & \multirow[b]{2}{*}{ SEM } & \multirow{2}{*}{$\frac{P \text {-value }}{F \text {-test }}$} \\
\hline & 1 & 2 & & \\
\hline Maximum daily temperature, ${ }^{\circ} \mathrm{C}$ & 26.0 & 28.4 & 1.04 & 0.13 \\
\hline Average daily temperature, ${ }^{\circ} \mathrm{C}$ & 20.5 & 22.9 & 0.97 & 0.10 \\
\hline Minimum daily temperature, ${ }^{\circ} \mathrm{C}$ & 15.3 & 17.7 & 0.95 & 0.11 \\
\hline Maximum dew point, ${ }^{\circ} \mathrm{C}$ & 18.1 & 19.7 & 0.84 & 0.20 \\
\hline Average dew point, ${ }^{\circ} \mathrm{C}$ & 15.3 & 17.5 & 0.92 & 0.12 \\
\hline Minimum dew point, ${ }^{\circ} \mathrm{C}$ & 12.0 & 15.0 & 1.08 & 0.07 \\
\hline Maximum humidity, \% & 92.5 & 92.9 & 1.02 & 0.77 \\
\hline Average humidity, \% & 74.6 & 73.4 & 1.94 & 0.67 \\
\hline Minimum humidity, $\%$ & 55.3 & 51.3 & 2.39 & 0.27 \\
\hline Maximum windspeed, $\mathrm{km} / \mathrm{h}$ & 23.7 & 22.2 & 1.10 & 0.34 \\
\hline Average windspeed, km/h & 12.1 & 10.3 & 0.88 & 0.16 \\
\hline Minimum windspeed, $\mathrm{km} / \mathrm{h}$ & 2.51 & 1.47 & 0.54 & 0.20 \\
\hline Maximum barometric pressure, $\mathrm{mm}$ & 742.4 & 744.1 & 0.59 & 0.06 \\
\hline Average barometric pressure, $\mathrm{mm}$ & 740.6 & 742.7 & 0.72 & 0.06 \\
\hline Minimum barometric pressure, mm & 738.8 & 741.3 & 0.61 & 0.02 \\
\hline Maximum $\mathrm{THI}^{2}$ & 78.0 & 82.1 & 1.76 & 0.12 \\
\hline Average THI & 67.2 & 71.0 & 1.48 & 0.10 \\
\hline Minimum THI & 59.2 & 62.3 & 1.30 & 0.12 \\
\hline Precipitation, $\mathrm{cm}$ & 0.82 & 0.32 & 0.19 & 0.10 \\
\hline
\end{tabular}

${ }^{1} F$-test for probability that study 1 versus study 2 differ.

${ }^{2} \mathrm{THI}=$ temperature-humidity index.

1. The amount of precipitation tended $(P<0.10)$ to be greater for study 2 compared with study 1 , indicating that the 2018 summer was hotter and drier than latespring 2018.

\section{Growth Performance}

Both studies started out with 40 calves (20 per treatment). Study 1 lost 1 calf due to respiratory disease and 1 calf became an outlier and eliminated due to insufficient CS consumption during weaning (causing BW loss). The calf was placed back on MR to gain BW. During study 2, when the summer heat resulted in moderate heat stress, 3 calves were lost with 1 due to respiratory disease, 1 due to dehydration from lack of drinking (cause unknown), and 1 due to scours. Also, 2 calves were deemed as statistical outliers due to very low BW gains. This resulted in 2 calves lost or removed when fed $22 \mathrm{CP} \mathrm{MR}$ and 5 calves lost when fed the 22AA MR over the course of the 2 studies.

The interaction of study by MR was nonsignificant $(P>0.12)$ for BW measurements and ADG calculations (Table 6 ). The interaction of study by week was significant $(P<0.01)$, but the interaction of study by MR by week was nonsignificant $(P>0.20)$. Initial weekly, final, and study average BW were similar $(P$ $>0.24$ ) for both studies, even though we would expect heat stress to have had more of an effect on BW in study 2 than study 1 . The study effect approached ( $P$ $<0.07$ ) significance due to the heat stress of study 2 , which reduced the ADG of calves during the first 14 $\mathrm{d}$ of the study. There was a tendency $(P<0.07)$ for the 0 to $14 \mathrm{~d}$ ADG to be affected by heat stress (data not shown), but the slower start did not carry through the rest of the study, and resulted in an overall similar 0 to $56 \mathrm{~d}$ ADG $(P>0.17)$ among study. Bateman et al. (2012) reported a decline in ADG as environmental temperature increased (approximately 1\% ADG change per $1^{\circ} \mathrm{C}$ ). Thus, heat stress increases the calf's maintenance requirement, which Hill et al. (2012) partially improved by feeding more MR.

The initial, weekly, and final calf BW, BW gain, and ADG were similar $(P>0.25)$ for calves fed both MR (Table 6). Increasing the EAA concentration of the 22AA MR to that of a $24 \%$ CP MR, but with a reduced $\mathrm{CP}$ concentration to $22 \% \mathrm{CP}$, did not improve calf growth performance in this study. Bai et al. (2020) reported feeding an EAA balanced $22 \% \mathrm{CP}$ MR with the EAA concentrations of a $24 \% \mathrm{CP}$ improved ADG during the crucial first 2 wk of life compared with a 20 , 22 , and $24 \%$ CP MR. Getting calves started correctly and growing during the first weeks of life by minimizing or eliminating disease and stress challenges is crucial to calf growth performance. Our data here numerically demonstrated an 18\% ADG improvement with large variation during the first $14 \mathrm{~d}$, which supports the work of Bai et al. (2020). Average daily gains for the remaining periods and overall study ADG were similar $(P>$ $0.17)$ for calves fed both MR. These data demonstrate that formulating an $22 \% \mathrm{CP}$ AA MR with the EAA 
Table 6. Body weight, BW gains, and ADG for calves fed a milk replacer (MR) formulated for $22 \% \mathrm{CP}$ $(22 \mathrm{CP})$ or containing greater AA concentrations (22AA) equal to $24 \% \mathrm{CP}$

\begin{tabular}{|c|c|c|c|c|c|c|}
\hline \multirow[b]{2}{*}{ Measurement } & \multicolumn{2}{|c|}{ MR } & \multirow[b]{2}{*}{ SEM } & \multicolumn{3}{|c|}{ Effects and interaction, $P$-value ${ }^{1}$} \\
\hline & $22 \mathrm{CP}$ & $22 \mathrm{AA}$ & & Study & MR & Study $\times$ MR \\
\hline Number of calves & 38 & 35 & - & - & - & - \\
\hline Death loss, number & 2 & 5 & - & - & - & - \\
\hline \multicolumn{7}{|l|}{$\mathrm{BW}, \mathrm{kg}$} \\
\hline Week 0 , initial & 39.9 & 39.9 & 0.59 & 0.63 & 0.92 & 0.35 \\
\hline Week 1 & 42.1 & 42.0 & 0.59 & & & \\
\hline Week 2 & 42.8 & 43.3 & 0.59 & & & \\
\hline Week 3 & 48.7 & 48.9 & 0.59 & & & \\
\hline Week 4 & 53.0 & 53.3 & 0.59 & & & \\
\hline Week 5 & 57.6 & 57.7 & 0.59 & & & \\
\hline Week 6 & 61.2 & 60.7 & 0.59 & & & \\
\hline Week 7 & 65.4 & 64.9 & 0.59 & & & \\
\hline Week 8 , final & 71.2 & 70.3 & 0.59 & & & \\
\hline Study average & 53.5 & 53.5 & 0.65 & & & \\
\hline \multirow{2}{*}{\multicolumn{7}{|c|}{ ADG }} \\
\hline & & & & & & \\
\hline $0-14 \mathrm{~d}, \mathrm{~g} / \mathrm{d}$ & 207.1 & 245.5 & 22.8 & 0.07 & 0.25 & 0.83 \\
\hline $0-28 \mathrm{~d}, \mathrm{~g} / \mathrm{d}$ & 468.9 & 478.0 & 16.2 & 0.27 & 0.69 & 0.13 \\
\hline $0-42 \mathrm{~d}, \mathrm{~g} / \mathrm{d}$ & 507.3 & 496.4 & 19.0 & 0.39 & 0.65 & 0.24 \\
\hline $0-56 \mathrm{~d}, \mathrm{~g} / \mathrm{d}$ & 568.6 & 552.4 & 20.6 & 0.18 & 0.55 & 0.22 \\
\hline
\end{tabular}

${ }^{1}$ Probability of $F$-test for effects of study, MR, and interaction.

concentration of a $24 \% \mathrm{CP}$ did not improve calf growth performance compared with calves fed a $22 \mathrm{CP}$ formulated MR.

\section{Dry Matter Intake, Feed Efficiency, and AA Intake}

Per experimental design, the MR DMI was the same for both MR treatments (Table 7 ). There was a significant $(P<0.01)$ study by week interaction $(0.02,0.05$, $0.09,0.14,0.21,0.61,1.39$, and $1.85 \mathrm{~kg} / \mathrm{d}$ for study 1 compared with $0.03,0.05,0.07,0.13,0.21,0.53,1.22$, and $1.78 \mathrm{~kg} / \mathrm{d}$ for study 2 for wk $1-8$, respectively) for CS DMI, which demonstrated that calves fed CS in study 2 consumed less CS DMI with experimental week compared with calves fed CS in study 1 . The reduction in CS DMI would be related to the heat stress experienced, which was visually observed during study 2. Chester-Jones et al. (2008) reported reduced starter intake during May through September compared with other months. McKnight (1978) reported reduced starter intake in summer compared with winter or fall. The study by MR interaction was nonsignificant $(P>$ 0.10 ) for CS DMI and total DMI (MR plus CS). Both the study effect and MR effect were nonsignificant $(P>$ 0.38 ) for CS DMI and total DMI. Heat stress and MR source demonstrated no effect on CS DMI and total DMI.

The study by MR interaction for feed conversion was nonsignificant $(P>0.10)$ across all summarized phases (Table 7). A study trend $(P<0.09)$ effect was detected for the 0 to $14 \mathrm{~d}$ and 0 to $42 \mathrm{~d}$ MR feeding phase for feed conversion expressed as kilogram of BW gain per total DMI for calves fed in study 2 compared with calves fed during study 1 . Because CS intake was affected by heat stress, study 2 calves demonstrated improved feed conversions compared with study 1 , which resulted in a significant $(P<0.05)$ study-by-week interaction for CS DMI. Hill et al. (2012) reported similar feed conversions for calves fed additional MR during summer heat stress. Marai et al. (1995) reported lower feed conversions for calves fed in summer compared with calves fed in the winter. Calculated feed conversions from the data of McKnight (1978) indicated lower feed conversion for summer-fed calves compared with calves fed during the other seasons.

The study by MR interaction, study main effect, and MR main effect for EAA intake were similar $(P>0.35)$ for all calves (MR plus CS; Table 8). Even though the EAA concentrations were greater for many of the EAA (Table 4) for calves fed the 22AA MR, the total EAA intakes were similar $(P>0.10)$ due to slight numerical differences in CS DMI and total DMI that overcame the differences in EAA intake during the MR feeding phase. In this study, the 22AA MR EAA formulation did not improve EAA intake.

\section{Frame Measurements}

The study by MR interaction was nonsignificant $(P$ $>0.10$ ) for all body frame measurements of HH, WH, HG, and BL (Table 9). Initial and final hip heights were similar $(P>0.11)$ for calves fed in both studies, 
Table 7. Dry matter intake of milk replacer (MR) and calf starter, and calculated feed conversions for calves fed a milk replacer (MR) formulated for $22 \% \mathrm{CP}(22 \mathrm{CP})$ or containing greater AA concentrations (22AA) equal to $24 \% \mathrm{CP}$

\begin{tabular}{|c|c|c|c|c|c|c|}
\hline \multirow[b]{2}{*}{ Measurement } & \multicolumn{2}{|c|}{ MR } & \multirow[b]{2}{*}{ SEM } & \multicolumn{3}{|c|}{ Effects and interaction, $P$-value ${ }^{1}$} \\
\hline & $22 \mathrm{CP}$ & $22 \mathrm{AA}$ & & Study & MR & Study $\times$ MR \\
\hline \multicolumn{7}{|l|}{ MR DMI, kg/d } \\
\hline Weeks 1 and 2 & 0.55 & 0.55 & - & - & - & - \\
\hline Weeks 3,4 , and 5 & 0.82 & 0.82 & - & - & - & - \\
\hline Week 6 & 0.41 & 0.41 & - & - & - & - \\
\hline \multicolumn{7}{|c|}{ Calf starter DMI, $\mathrm{kg} / \mathrm{d}$} \\
\hline Week 1 & 0.03 & 0.02 & 0.04 & 0.39 & 0.45 & 0.76 \\
\hline Week 2 & 0.06 & 0.04 & 0.04 & & & \\
\hline Week 3 & 0.10 & 0.06 & 0.04 & & & \\
\hline Week 4 & 0.17 & 0.10 & 0.04 & & & \\
\hline Week 5 & 0.23 & 0.19 & 0.04 & & & \\
\hline Week 6 & 0.60 & 0.54 & 0.04 & & & \\
\hline Week 7 & 1.33 & 1.29 & 0.04 & & & \\
\hline Week 8 & 1.83 & 1.80 & 0.04 & & & \\
\hline Study average & 0.54 & 0.50 & 0.04 & & & \\
\hline \multicolumn{7}{|l|}{ Total DMI, kg/d } \\
\hline Week 1 & 0.58 & 0.57 & 0.04 & 0.33 & 0.49 & 0.70 \\
\hline Week 2 & 0.60 & 0.59 & 0.04 & & & \\
\hline Week 3 & 0.92 & 0.89 & 0.04 & & & \\
\hline Week 4 & 0.99 & 0.93 & 0.04 & & & \\
\hline Week 5 & 1.05 & 1.01 & 0.04 & & & \\
\hline Week 6 & 1.01 & 0.95 & 0.04 & & & \\
\hline Week 7 & 1.33 & 1.29 & 0.04 & & & \\
\hline Week 8 & 1.83 & 1.80 & 0.04 & & & \\
\hline Study average & 1.04 & 1.00 & 0.04 & & & \\
\hline \multicolumn{7}{|l|}{ Total DMI } \\
\hline $0-56 \mathrm{~d}, \mathrm{~kg}$ & 58.1 & 56.2 & 1.70 & 0.29 & 0.37 & 0.63 \\
\hline \multicolumn{7}{|l|}{ Gain/DMI, kg/kg } \\
\hline $0-14 \mathrm{~d}, \mathrm{~g} / \mathrm{d}$ & 0.35 & 0.42 & 0.04 & 0.09 & 0.20 & 0.73 \\
\hline $0-28 \mathrm{~d}, \mathrm{~g} / \mathrm{d}$ & 0.61 & 0.64 & 0.02 & 0.26 & 0.21 & 0.18 \\
\hline $0-42 \mathrm{~d}, \mathrm{~g} / \mathrm{d}$ & 0.59 & 0.60 & 0.01 & 0.06 & 0.41 & 0.12 \\
\hline $0-56 \mathrm{~d}, \mathrm{~g} / \mathrm{d}$ & 0.54 & 0.54 & 0.01 & 0.45 & 0.83 & 0.11 \\
\hline
\end{tabular}

${ }^{1}$ Probability of $F$-test for effects of study, milk replacer, and interaction.

but the gain (final - initial) was greater $(P<0.01)$ for study 1 compared with study 2 (data not shown). The initial, final, and gains in $\mathrm{WH}$ were similar $(P>$ $0.35)$ for calves in both studies. In contrast, differences were observed for study 1 compared with study 2 for initial and final $\mathrm{HG}$, but the gain was similar $(P>$ $0.88)$ across both studies. The initial, final, and BL gains were greater $(P<0.01)$ for calves in study 1 compared with calves in study 2 (data not shown). Calves sourced from auction barns for study 2 were

Table 8. Amino acid intake (milk replacer plus calf starter) for calves fed a milk replacer (MR) formulated for $22 \% \mathrm{CP}(22 \mathrm{CP})$ or containing greater AA concentrations (22AA) equal to $24 \% \mathrm{CP}$

\begin{tabular}{|c|c|c|c|c|c|c|}
\hline \multirow[b]{2}{*}{ Item, $\mathrm{g} / \mathrm{d}$} & \multicolumn{2}{|c|}{ MR } & \multirow[b]{2}{*}{ SEM } & \multicolumn{3}{|c|}{ Effects and interaction, $P$-value ${ }^{1}$} \\
\hline & $22 \mathrm{CP}$ & $22 \mathrm{AA}$ & & Study & $\mathrm{MR}$ & Study $\times$ MR \\
\hline $\operatorname{Arg}$ & 11.6 & 11.0 & 0.59 & 0.38 & 0.47 & 0.75 \\
\hline His & 5.8 & 5.5 & 0.27 & 0.39 & 0.48 & 0.73 \\
\hline Ile & 12.1 & 11.8 & 0.42 & 0.40 & 0.50 & 0.70 \\
\hline Leu & 22.0 & 21.4 & 0.78 & 0.40 & 0.50 & 0.71 \\
\hline Lys & 20.7 & 20.3 & 0.54 & 0.42 & 0.52 & 0.67 \\
\hline Met & 6.0 & 6.1 & 0.14 & 0.43 & 0.54 & 0.65 \\
\hline Phe & 10.1 & 9.7 & 0.48 & 0.38 & 0.48 & 0.73 \\
\hline Thr & 12.7 & 12.4 & 0.35 & 0.41 & 0.52 & 0.68 \\
\hline Trp & 3.5 & 3.4 & 0.12 & 0.40 & 0.50 & 0.70 \\
\hline Val & 13.6 & 12.2 & 0.49 & 0.40 & 0.50 & 0.70 \\
\hline Total EAA & 117.9 & 114.4 & 4.24 & 0.39 & 0.50 & 0.70 \\
\hline
\end{tabular}

${ }^{1}$ Probability of $F$-test for effects of study, MR, and interaction. 
Table 9. Body frame measurements for calves fed a milk replacer (MR) formulated for $22 \% \mathrm{CP}(22 \mathrm{CP})$ or containing greater AA concentrations (22AA) equal to $24 \% \mathrm{CP}$

\begin{tabular}{|c|c|c|c|c|c|c|}
\hline \multirow{2}{*}{$\begin{array}{l}\text { Measurement, } \\
\mathrm{cm}\end{array}$} & \multicolumn{2}{|c|}{ MR } & \multirow[b]{2}{*}{ SEM } & \multicolumn{3}{|c|}{ Effects and interaction, $P$-value ${ }^{1}$} \\
\hline & $22 \mathrm{CP}$ & $22 \mathrm{AA}$ & & Study & MR & Study $\times$ MR \\
\hline \multicolumn{7}{|l|}{ Hip height } \\
\hline Initial & 80.9 & 81.1 & 0.51 & 0.25 & 0.70 & 0.24 \\
\hline Final & 89.9 & 89.6 & 0.61 & 0.11 & 0.58 & 0.40 \\
\hline Gain & 8.94 & 8.38 & 0.37 & 0.01 & 0.31 & 0.72 \\
\hline \multicolumn{7}{|l|}{ Withers height } \\
\hline Initial & 76.3 & 76.7 & 0.46 & 0.36 & 0.33 & 0.26 \\
\hline Final & 84.7 & 85.0 & 0.51 & 0.92 & 0.64 & 0.76 \\
\hline Gain & 8.38 & 8.25 & 0.41 & 0.36 & 0.81 & 0.52 \\
\hline \multicolumn{7}{|l|}{ Heart girth } \\
\hline Initial & 78.3 & 78.2 & 0.47 & 0.01 & 0.75 & 0.94 \\
\hline Final & 94.8 & 93.8 & 0.85 & 0.01 & 0.22 & 0.73 \\
\hline Gain & 16.5 & 15.6 & 0.60 & 0.89 & 0.27 & 0.77 \\
\hline \multicolumn{7}{|l|}{ Body length } \\
\hline Initial & 52.5 & 56.3 & 0.58 & 0.01 & 0.48 & 0.64 \\
\hline Final & 62.8 & 62.7 & 0.63 & 0.01 & 0.89 & 0.73 \\
\hline Gain & 10.3 & 9.8 & 0.66 & 0.01 & 0.59 & 0.59 \\
\hline
\end{tabular}

${ }^{1}$ Probability of $F$-test for effects of study, MR, and interaction.

smaller $(P<0.01)$ in both $\mathrm{HG}$ and $\mathrm{BL}$, and $\mathrm{HH}$ and wither heights were numerically lower, which indicated that calves sourced for study 2 were smaller possibly due to maternal heat stress. Calves experiencing heat stress during study 2 gained less $\mathrm{HH}$ and BL. Marai et al. (1995) reported reduced Holstein calf growth rates during the summer compared with winter. Collier et al. (1982) and Wolfenson et al. (1988) reported that calf birth weights were lower when dairy cows experienced heat stress during the dry period. Tao and Dahl (2013) reported that maternal heat stress may have carryover effects on subsequent newborn calf growth.

Calves fed either MR were similar $(P>0.20)$ in initial and final $\mathrm{HH}$, wither height, $\mathrm{HG}$, and BL gains (Table 9). In this study, increasing the AA supply through the MR did not influence body frame measurements. Amino acids are required for frame growth, and this is the most efficient time in the animal's life cycle to grow the skeletal frame (Le Cozler et al., 2008). Bai et al. (2020) reported similar frame growth for neonatal calves fed a $22 \% \mathrm{CP}$ and $22 \% \mathrm{CP}$ containing specific EAA concentration of a $24 \%$ CP MR. Jaeger et al. (2020c) reported that feeding a modified accelerated MR program resulted in greater hip width growth rates. Thus, it takes both EAA and energy in the proper balance to drive frame growth.

\section{Health Performance}

There was no study by MR interaction $(P>0.58)$ for fecal scores, whether expressed as total days for the study or number of days during the week for the 6 wk that MR treatments were fed (Table 10). Calves in study 1 demonstrated more $(P<0.01)$ days with fecal score of 0 and less $(P<0.01)$ days with fecal score 2 than calves fed during study 2 , which demonstrated that calves in study 2 experienced more scours due to heat stress (data not shown). Heat stress has been shown to increase the incidence of scours (Roland et al., 2016). Calves with fecal scores of 2 and 3 were considered to have scours, and fecal scores of 0 and 1 were considered normal with no scours.

Calves fed the 22AA MR demonstrated fewer fecal scores of 0 for total days $(P<0.03)$ or number of days during the week $(P<0.01)$ compared with calves fed $22 \mathrm{CP}$ MR. Total days of fecal score 2 or 3 and number of days during the week were similar $(P<0.15)$ for calves fed 22AA MR compared with calves fed 22CP. Calves fed 22AA MR tended to have greater $(P<0.06)$ total days of fecal score 3 and number of days during the week $(P<0.07)$. Thus, calves fed the $22 \mathrm{AA}$ MR with greater concentrations of synthetic EAA demonstrated more scours than calves fed lower concentrations of synthetic EAA. The use of synthetic EAA reduced inclusion rate of all milk protein ingredients, allowing for increased NFC concentrations for the $22 \mathrm{AA} \mathrm{MR}$. The increased NFC concentration was attributed a greater lactose concentration (Table 3). Davis and Drackley (1998) cited research that high lactose intake can lead to an increase incidence of scours. Whole milk on a DM basis would contain less than 40 to $45 \%$ lactose (NRC, 2001; Berends et al., 2020), thus increasing lactose concentrations could influence scour incidences. Berends et al. (2020) reported that exchanging fat for lactose in MR reduced the number of health events.

There were no study by MR interactions $(P>0.50)$, study, or MR effects on nasal and eye/ear scores (data not shown). Overall, calves were healthy; feeding a 
Table 10. Fecal scores for calves fed a milk replacer (MR) formulated for $22 \% \mathrm{CP}(22 \mathrm{CP})$ or containing greater AA concentrations (22AA) equal to $24 \% \mathrm{CP}$

\begin{tabular}{|c|c|c|c|c|c|c|}
\hline \multirow[b]{2}{*}{ Score } & \multicolumn{2}{|c|}{ MR } & \multirow[b]{2}{*}{ SEM } & \multicolumn{3}{|c|}{ Effects and interaction, $P$-value ${ }^{1}$} \\
\hline & $22 \mathrm{CP}$ & $22 \mathrm{AA}$ & & Study & MR & Study $\times$ MR \\
\hline \multicolumn{7}{|c|}{ Total days of fecal scores ${ }^{2}$} \\
\hline Score $=0$ & 25.0 & 22.4 & 0.81 & 0.01 & 0.03 & 0.59 \\
\hline Score $=1$ & 10.3 & 11.4 & 0.75 & 0.11 & 0.24 & 0.93 \\
\hline Score $=2$ & 5.2 & 5.9 & 0.48 & 0.01 & 0.26 & 0.87 \\
\hline Score $=3$ & 1.0 & 1.7 & 0.33 & 0.78 & 0.06 & 0.27 \\
\hline \multicolumn{7}{|c|}{ Fecal scores, $\mathrm{d} / \mathrm{wk}$} \\
\hline Score $=0$ & 4.2 & 3.7 & 0.13 & 0.01 & 0.01 & 0.57 \\
\hline Score $=1$ & 1.7 & 1.9 & 0.12 & 0.05 & 0.15 & 0.94 \\
\hline Score $=2$ & 0.9 & 1.0 & 0.08 & 0.01 & 0.26 & 0.86 \\
\hline Score $=3$ & 0.2 & 0.3 & 0.06 & 0.72 & 0.07 & 0.24 \\
\hline
\end{tabular}

${ }^{1}$ Probability of $F$-test for effects of study, MR, and interaction.

${ }^{2}$ Fecal score $=0-3 ; 0=$ normal, $\geq 2=$ scours.

$22 \mathrm{CP}$ or $22 \mathrm{AA} \mathrm{MR}$ resulted in similar $(P>0.15)$ nasal and eye/ear scores (data not shown), but the calves fed 22AA MR demonstrated lower fecal scores.

\section{Economic Analysis}

The MR feeding cost $(\mathrm{MR}$ DMI $\times \$ / \mathrm{kg})$ was the same for study 1 and 2 due to the same feeding rates, but feeding the $22 \mathrm{AA} \mathrm{MR}$ resulted in a $\$ 0.07$ per calf per day savings in feed costs compared with the calves fed 22CP (Table 11) for the $42 \mathrm{~d}$ MR feeding phase. The total MR cost per calf per the $42 \mathrm{~d}$ MR feeding period was greater $(P<0.01)$ for calves fed $22 \mathrm{CP}$ than calves fed 22AA MR, which is approximately a $4.7 \%$ reduction in MR feed costs. Bai et al. (2020) reported that calves fed a specific EAA-formulated MR of a $24 \%$ $\mathrm{CP}$, but reduced $\mathrm{CP}$ to $22 \%$ (similar to the AA MR treatment in this study) resulted in a lower cost per kilogram of BW gain compared with calves fed a $24 \%$ CP MR.

The study by MR interaction, study effect, and MR effect were similar $(P>0.38)$ for calves fed both MR treatments. The total daily cost of CS (DMI of CS $\times$ $\$ / \mathrm{kg}$ of CS $)$ per calf was similar $(P>0.10)$ for calves fed both treatments totaling, $\$ 14.71$ and $\$ 13.71$ due to the nonsignificant numerically lower CS intake for calves fed 22AA MR. Total feed costs per day and per study calf $(\mathrm{MR}+\mathrm{CS})$ were lower $(P<0.01)$ for calves fed AA MR compared with calves fed 22CP MR. The total feed cost per calf per experiment was $\$ 4.79$ for calves fed 22AA MR compared with calves fed $22 \mathrm{CP}$ $\mathrm{MR}$, however the numerical differences in BW gains, CS intake, and total feed intake resulted in a similar total feed cost per kilogram of BW gain $(P>0.44)$ for calves fed both treatments. In our study, we found that feeding calves an EAA formulated MR (22AA) compared with a $\mathrm{CP}$ formulated MR demonstrated the hypothesis of lowered feed cost per day with similar growth performance, but resulted in similar feed cost per kilogram of BW gain under current study conditions. The differences in feed costs resulted in small numerical differences between treatments in growth performance and the effects of heat stress resulted in lower feed costs on a per day basis, but the total cost

Table 11. Cost $(\$)$ per day for milk replacer (MR), pelleted calf starter (CS), and total cost per day and total cost per kilogram of $\mathrm{BW}$ gain for calves fed a MR formulated for $22 \% \mathrm{CP}(22 \mathrm{CP})$ or containing greater AA concentrations (22AA) equal to $24 \% \mathrm{CP}$

\begin{tabular}{|c|c|c|c|c|c|c|}
\hline \multirow[b]{2}{*}{ Item } & \multicolumn{2}{|c|}{ MR } & \multirow[b]{2}{*}{ SEM } & \multicolumn{3}{|c|}{ Effects and interaction, $P$-value ${ }^{1}$} \\
\hline & $22 \mathrm{CP}$ & $22 \mathrm{AA}$ & & Study & MR & Study $\times$ MR \\
\hline $\mathrm{MR}, \$ / \mathrm{d}, 0-42 \mathrm{~d}$ & 1.92 & 1.85 & $<0.01$ & - & 0.01 & - \\
\hline Total MR, $\$$ /calf & 83.20 & 79.44 & 0.06 & - & 0.01 & - \\
\hline $\mathrm{CS}, \$ / \mathrm{d}, 0-56 \mathrm{~d}$ & 0.23 & 0.22 & 0.02 & 0.39 & 0.45 & 0.76 \\
\hline Total CS, $\$ /$ calf & 14.71 & 13.71 & 0.80 & 0.26 & 0.34 & 0.69 \\
\hline Total feed cost, $\$ / \mathrm{d}$ & 1.67 & 1.60 & 0.02 & 0.56 & 0.01 & 0.46 \\
\hline Total feed cost, $\$ /$ calf & 97.94 & 93.15 & 0.80 & 0.43 & 0.01 & 0.38 \\
\hline $\begin{array}{l}\text { Total feed cost, } \$ / \mathrm{kg} \text { of } \mathrm{BW} \\
\text { gain per calf }\end{array}$ & 3.25 & 3.16 & 0.10 & 0.23 & 0.45 & 0.27 \\
\hline
\end{tabular}

${ }^{1}$ Probability of $F$-test for treatment. 
of gain was similar. Thus, the study hypothesis was partially confirmed in that similar growth performance can be achieved with a lesser feed cost, but the total cost per kilogram of BW gain was similar.

\section{CONCLUSIONS}

The study objective was partially achieved by feeding a MR containing greater concentrations of EAA using synthetic EAA, but the same $22 \% \mathrm{CP}$ (equal to $24 \%$ $\mathrm{CP}$ EAA MR), while reducing the $\mathrm{CP}$ concentration for achieving similar performance at a reduced cost. The use of synthetic EAA to supply key limiting AA can be used at concentrations to meet the EAA requirements for growing neonatal Holstein calves instead of CP, and reducing the cost of more expensive MR ingredients reduces the total feed cost per calf. This study demonstrated similar growth performance, feed intake, feed conversions, and frame growth for both MR. Therefore, similar growth performance can be achieved by feeding an EAA-fortified MR with less $\mathrm{CP}$, which reduced feed costs under current study conditions.

\section{ACKNOWLEDGMENTS}

The authors express their great appreciation to Janet Casper of Casper's Calf Ranch for the use of the research facilities, feeding and management assistance, and supplying the Holstein bull calves. The authors appreciate the assistance of Wendy Pearson, Abigayle Bacon, Bethany Lawrence (Casper's Calf Ranch, Freeport, IL), and Heidi Jones (Furst-McNess, Freeport, IL) in weighing and measuring calves. Appreciation is extended to Brandon Scharping and the Lena Veterinary Clinic for their assistance in providing veterinarian care and assistance. The authors greatly acknowledge the contribution of Milk Specialties (Eden Prairie, MN) for manufacturing and supplying the milk replacers and partial financial support of the project and FurstMcNess (Freeport, IL) for supplying the calf starter. This research was partially funded by Milk Specialties Global (Eden Prairie, MN), Furst-McNess Company (Freeport, IL), and the Discipline Construction Fund project of Gansu Agricultural University (Lanzhou, China; GAU-XKJS-2018-039). At the time of the studies, David P. Casper was co-owner of Casper's Calf Ranch LLC, a contract research facility, and Kayla Hultquist was employed by Furst-McNess. The remaining authors declare no conflicts of interest.

\section{REFERENCES}

AOAC International. 2019. Official Methods of Analysis, 21st ed. AOAC Int., Rockville, MD.
Bai, Y., T. Liu, K. Hultquist, J. Wu, and D. P. Casper. 2020. Feeding an amino acid formulated milk replacer for Holstein calves. J. Anim. Sci. 98:skaa099. https://doi.org/10.1093/jas/skaa099.

Bar-Peled, U., B. Robinzon, E. Maltz, H. Tagari, Y. Folman, I. Bruckental, H. Voet, H. Gacitua, and A. R. Lehrer. 1997. Increased weight gain and effects on production parameters of Holstein heifer calves that were allowed to suckle from birth to six weeks of age. J. Dairy Sci. 80:2523-2528. https://doi.org/10.3168/jds.S0022 -0302(97)76205-2.

Bateman, H. G. II, T. M. Hill, J. M. Aldrich, R. T. L. Schlotterbeck, and J. L. Firkins. 2012. Meta analysis of the impact of initial serum protein concentration and empirical prediction model for growth of neonatal Holstein calves through 8 weeks of age. J. Dairy Sci. 95:363-369. https://doi.org/10.3168/jds.2011-4594.

Beede, D. K. 2012. What will our ruminants drink? Anim. Front. 2:36-43. https://doi.org/10.2527/af.2012-0040.

Berends, H., H. van Laar, L. N. Leal, W. J. J. Gerrits, and J. MartinTereso. 2020. Effects of exchanging lactose for fat in milk replacers on ad libitum feed intake and growth performance in dairy calves. J. Dairy Sci. 103:4275-4287. https://doi.org/10.3168/jds .2019-17382.

Borderas, T. F., A. M. de Passillé, and J. Rushen. 2009. Feeding behavior of calves fed small or large amounts of milk. J. Dairy Sci. 92:2843-2852. https://doi.org/10.3168/jds.2008-1886.

Chester-Jones, H. D. M. Ziegler, R. Larson, C. Soderholm, S. Hayes, J. G. Linn, M. Raeth-Knight, G. Golombeski, and S. Broadwater. 2008. Applied calf research from birth to six months. Pages 106-112 in Proc. 4 State Dairy Nutr. Manage. Conf., Dubuque, IA. Iowa State University Press, Ames.

Collier, R. J., S. G. Doelger, H. H. Head, W. W. Thatcher, and C. J. Wilcox. 1982. Effects of heat stress during pregnancy on maternal hormone concentrations, calf birth weight and postpartum milk yield of Holstein cows. J. Anim. Sci. 54:309-319. https://doi.org/ $10.2527 /$ jas $1982.542309 x$.

Davis, C. L., and J. K. Drackley. 1998. The Development, Nutrition, and Management of the Young Calf. Iowa State University Press, Ames, IA.

DuBois, M., K. A. Gilles, J. K. Hamilton, P. A. Rebers, and F. Smith. 1956. Colorimetric method for determination of sugars and related substances. Anal. Chem. 28:350-356. https://doi.org/10.1021/ ac60111a017.

FASS. 2010. Guide for the Care and Use of Agricultural Animals in Research and Teaching, 3rd ed. Fed. Anim. Sci. Soc., Champaign, IL.

Guzelbektes, H., A. Coskun, and I. Sen. 2007. Relationship between the degree of dehydration and the balance of acid-base changes in dehydrated calves with diarrhea. Bull. Vet. Inst. Pulawy 51:83-87.

Hall, M. B. 2009. Analysis of starch, including maltooligosaccharides, in animal feeds: A comparison of methods and a recommended method for AOAC collaborative study. J. AOAC Int. 92:42-49. https://doi.org/10.1093/jaoac/92.1.42.

He, Z. M., G. P. Li, and D. S. Zhu. 2016. Laboratory animals management and use guidelines. Mammalian Experimental Animals, Bovine. Science Press, Beijing, China.

Hill, T. M., J. M. Aldrich, R. L. Schlotterbeck, and H. G. Bateman II.. 2006. Effects of feeding calves different rates and protein concentrations of twenty percent fat milk replacers on growth during the neonatal period. Prof. Anim. Sci. 22:252-260. https://doi.org/10 .15232/S1080-7446(15)31101-3.

Hill, T. M., J. M. Aldrich, R. L. Schlotterbeck, and H. G. Bateman II.. 2007. Amino acids, fatty acids, and fat sources for calf milk replacers. Prof. Anim. Sci. 23:401-408. https://doi.org/10.15232/S1080 -7446(15)30995-5 https://doi.org/10015232/s1080-7446(15)30995 $-5$.

Hill, T. M., H. G. Bateman II, J. M. Aldrich, and R. L. Schlotterbeck. 2012. Case study: Effect of feeding rate and weaning age of dairy calves feds a conventional milk replacer during warm summer months. Prof. Anim. Sci. 28:125-130. https://doi.org/10.15232/ S1080-7446(15)30324-7.

Jaeger, B. M., D. Ziegler, D. Schimek, B. Ziegler, H. Chester-Jones, and D. P. Casper. 2020b. Growth performance of new born calves 
fed a $24 \%$ crude protein $20 \%$ fat milk replacer at different feeding rates. Appl. Anim. Sci. 36. In press.

Jaeger, B. M., D. Ziegler, D. Schimek, B. Ziegler, H. Chester-Jones, and D. P. Casper. 2020c. Dairy calf growth performance when fed a modified accelerated milk replacer program. Appl. Anim. Sci. 36:352-366. https://doi.org/10.15232/aas.2019-01878.

Jaeger, B. M., D. Ziegler, D. Schimek, B. Ziegler, M. Raeth, H. Chester-Jones, and D. P. Casper. 2020a. Growth performance of newborn dairy calves fed a milk replacer with 2 protein concentrations at 2 feeding rates. Appl. Anim. Sci. 36:48-56. https://doi.org/10 .15232 /aas.2019-01866.

Jasper, J., and D. M. Weary. 2002. Effects of ad libitum milk intake on dairy calves. J. Dairy Sci. 85:3054-3058. https://doi.org/10.3168/ jds.S0022-0302(02)74391-9.

Krishnamoorthy, U., T. V. Muscato, C. J. Sniffen, and P. J. Van Soest. 1982. Nitrogen fractions in selected feedstuffs. J. Dairy Sci. 65:217-225. https://doi.org/10.3168/jds.S0022-0302(82)82180-2.

Le Cozler, Y., V. Lollivier, P. Lacasse, and C. Disenhaus. 2008. Rearing strategy and optimizing first-calving targets in dairy heifers: A review. Animal 2:1393-1404. https://doi.org/10.1017/ S1751731108002498.

Marai, I. F. M., A. A. Habeeb, A. H. Daader, and H. M. Yousef. 1995. Effects of Egyptian subtropical summer condition and the heatstress alleviation technique of water spray and a diaphoretic on the growth and physiological functions of Friesian calves. J. Arid Environ. 30:219-225. https://doi.org/10.1016/S0140-1963(05)80073-4.

McGuirk, S. 2013. Calf Health Scoring Chart. University of Wisconsin, School of Veterinary Medicine. Accessed Sept. 1, 2015. https: //www.vetmed.wisc.edu/dms/fapm/fapmtools/8calf/calf_health scoring_chart.pdf.

McKnight, D. R. 1978. Performance of newborn dairy calves in hutch housing. Can. J. Anim. Sci. 58:517-520. https://doi.org/10.4141/ cjas78-066.

Moore, S., and W. H. Stein. 1963. Chromatographic determination of amino acids by the use of automatic recording equipment. Methods Enzymol. 6:819-831. https://doi.org/10.1016/0076-6879(63)06257 -1 .

NRC. 2001. Nutrient Requirements of Dairy Cattle, 7th rev. ed. Natl. Acad. Sci., Washington, DC.
Quigley, J. 2007. Calculating ME in Milk and Milk Replacer. Calf Notes \#122. Accessed Dec. 28, 2019. https://www.calfnotes.com/ pdfiles/CN122.pdf.

Roland, L., M. Drillich, D. Klein-Jöbstl, and M. Iwersen. 2016. Invited review: Influence of climatic conditions on the development performance and health of calves. J. Dairy Sci. 99:2438-2452. https:// doi.org/10.3168/jds.2015-9901.

Spiers, D. E., J. N. Spain, M. J. Leonard, and M. C. Lucy. 2001. Effect of cooling strategy and night temperature on dairy cow performance during heat stress. Pages 45-55 in Livestock Environment VI: Proceedings of the 6th International Symposium, Louisville, KY. American Society of Agricultural and Biological Engineers, St. Joseph, MI.

Steele, R. G. D., and J. H. Torrie. 1980. Principles and Procedures of Statistics, 2nd ed. McGraw-Hill Book Co., New York, NY.

Tao, S., and G. E. Dahl. 2013. Invited review: Heat stress effects during late gestation on dry cows and their calves. J. Dairy Sci. 96:4079-4093. https://doi.org/10.3168/jds.2012-6278 https://dor .org/10.3168/jds.2012-6278.

Vieira, A. D. P., V. Guesdon, A. M. de Passille, M. A. G. von Keyserlingk, and D. M. Weary. 2008. Behavioural indicators of hunger in dairy calves. Appl. Anim. Behav. Sci. 109:180-189. https://doi .org/10.1016/j.applanim.2007.03.006.

Vitali, A., M. Segnalini, L. Bertocchi, U. Bernabucci, A. Nardone, and N. Lacetera. 2009. Seasonal pattern of mortality and relationships between mortality and temperature-humidity index in dairy cows. J. Dairy Sci. 92:3781-3790. https://doi.org/10.3168/jds.2009 $-2127$.

Wolfenson, D., I. Flamenbaum, and A. Berman. 1988. Dry period heat stress relief effects on prepartum progesterone, calf birth weight, and milk production. J. Dairy Sci. 71:809-818. https://doi.org/10 .3168/jds.S0022-0302(88)79621-6.

\section{ORCIDS}

Ting Liu (®) https://orcid.org/0000-0003-3760-8784

Kayla Hultquist (ㄴ) https://orcid.org/0000-0002-6467-5109

David P. Casper @ https://orcid.org/0000-0002-0666-8808 